\title{
In vitro antihelmintic effect of fifteen tropical plant extracts on excysted flukes of Fasciola hepatica
}

José Manuel Alvarez-Mercado ${ }^{1}$, Froylán Ibarra-Velarde ${ }^{1 *}$, Miguel Ángel Alonso-Díaz $^{2}$, Yolanda Vera-Montenegro ${ }^{1}$, José Guillermo Avila-Acevedo ${ }^{3}$ and Ana María García-Bores ${ }^{3}$

\begin{abstract}
Background: Fasciolosis due to Fasciola hepatica is the most important hepatic disease in veterinary medicine. Its relevance is important because of the major economical losses to the cattle industry such as: reduction in milk, meat and wool production; miscarriages, anemia, liver condemnation and occasionally deaths, are estimated in billons of dollars.

The emergence of fluke resistance due to over or under dosing of fasciolides as well as environmental damage produced by the chemicals eliminated in field have stimulated the need for alternative methods to control Fasciola hepatica. The aim of this study was to evaluate the in vitro anthelmintic effect of fifteen tropical plant extracts used in tradicional Mexican medicine, on newly excysted flukes of Fasciola hepatica.
\end{abstract}

Results: The flukes were exposed in triplicate at 500, 250 and $125 \mathrm{mg} / \mathrm{L}$ to each extract. The efficacy was assessed as the mortality rate based on the number of live and dead flukes after 24,48 and $72 \mathrm{~h}$ post-exposure. The plants with anthelmintic effect were evaluated once again with a concentration of $375 \mathrm{mg} / \mathrm{L}$ in order to confirm the results and to calculate lethal concentrations at 50\%, 90\% and 99\% ( $\mathrm{LC}_{50}, \mathrm{LC}_{90}$, and $\left.\mathrm{LC} \mathrm{C}_{99}\right)$. Plant extracts of Lantana camara, Bocconia frutescens, Piper auritum, Artemisia mexicana and Cajanus cajan had an in vitro anthelmintic effect $(\mathrm{P}<0.05)$. The $\mathrm{LC}_{50}, \mathrm{LC}_{90}$ and $\mathrm{LC} \mathrm{C}_{99}$ to A. mexicana, C. cajan and B. frutescens were $92.85,210.44$ and $410.04 \mathrm{mg} / \mathrm{L}$, $382.73,570.09$ and $788.9 \mathrm{mg} / \mathrm{L}$ and $369.96,529.94$ and $710.34 \mathrm{mg} / \mathrm{L}$, respectively.

Conclusion: It is concluded that five tropical plant extracts had promising anthelmintic effects against $F$. hepatica. Further studies on toxicity and in vivo biological evaluation in ruminant models might help to determine the anthelmintic potential of these plant extracts.

Keywords: Plant extracts, Fasciola hepatica, Anthelmintic activity, In vitro

\section{Background}

Fasciolosis caused by Fasciola hepatica has a worldwide distribution affecting cattle, sheep, goats, pigs, horses, rabbits and humans as well. It causes major economical losses to the cattle industry (estimated in billons of dollars) by decreasing milk and/or meat production, low reproductive efficiency, liver seizures in slaughterhouses, high costs to control parasitism and deaths [1,2].

\footnotetext{
* Correspondence: ibarraf@unam.mx

'Departamento de Parasitología, Facultad de Medicina Veterinaria y Zootecnia, Universidad Nacional Autónoma de México. Cd. Universitaria C.P. 04510 México, DF, Mexico

Full list of author information is available at the end of the article
}

The control of this disease has been based on the application of anthelmintics, but due to the development of resistance it seems that the efficacy of some chemical drugs has decreased [3,4]. The use of plants with anthelmintic activity may be an alternative to fluke control, given the great diversity of ecosystems. The opportunity of finding bioactive compounds with anti-fluke properties significantly increases because, secondary metabolites (SM) are the most important compounds as new alternatives for parasite control. Some SM such us alkaloids, saponins, skimmiarins $\mathrm{A}$ and $\mathrm{C}$, tannins, flavonoids, terpenes (mono, di and sesquiterpenes) have been shown to be active against a wide range of parasites [5]. 
Recent studies have reported the anthelmintic effect of plants such as Artemisia mexicana, Mentha piperita, Achillea millefolium, Allium sativum, Piper nigrum, and Carica papaya with parasiticidal effects against $F$. hepatica [6-8].

Veracruz is the Mexican state with the highest livestock production in the country [9] and parasitic illnesses are the main threat to grazing bovines in this region. Because of the great diversity of ecosystems, the native vegetation of Veracruz has a wide variety of plant species (containing variable levels of SM) which potentially could be used as a fascioliscide. However, studies to evaluate the effect of plants with possible anthelmintic properties against $F$. hepatica in the area have been not carried out. The aim of the present study was to evaluate the anthelmintic effect of fifteen plants extracts from Veracruz, Mexico.

\section{Methods}

Plant material

Fresh leaves (700 g) of Acacia cornigera (2147 IZTA), Acacia farnesiana (2164 IZTA), Artemisia absinthium (2155 IZTA), Artemisia mexicana (2156 IZTA), Bocconia frutescens (2153 IZTA), Cajanus cajan (2164 IZTA), Cordia spp, Hibiscus rosa - sinensis (2149 IZTA), Lantana camara (2160 IZTA), Leucaena diversifolia (2169 IZTA), Melia azedarach (2161 IZTA), Mentha sp (2163 IZTA), Ocimum basilicum (2154 IZTA), Piper auritum
(2165 IZTA) and Teloxys ambrosioides (2157 IZTA) were collected from villages in Veracruz, Mexico.

Prior to the beginning of this trial, samples of different plants were collected and identified by Dr. Edith López Villafranco of the IZTA Herbarium at the Facultad de Estudios Superiores Iztacala for the purpose of authenticating them. A voucher specimen was deposited in the IZTA herbarium for future reference (a reference number was assigned). The plants were chosen based on the traditional practices [10-12]; moreover reports of other authors [7,13-15] and interviews with local people have shown to be effective in finding remedies against other parasites.

\section{Extraction procedure}

Extraction procedures were undertaken in the phytochemistry laboratory of FES Iztacala and the evaluation of in vitro anthelmintic efficacy was carried out in the laboratory of experimental chemotherapy of the parasitology department, (FMVZ-UNAM).

The leaves of each plant $(100 \mathrm{~g})$ were dried in an oven for three days at $60^{\circ} \mathrm{C}$, ground into powder and sequentially extracted with hexane, ethyl acetate and methanol. The extracts were filtered and successively concentrated. Each extract was concentrated under low pressure at low temperature and revolutions per minute (RPM) as follows: 1) hexane, at $\left.60^{\circ} \mathrm{C}, 50 \mathrm{RPM}, 2\right)$ ethyl acetate, at $78^{\circ} \mathrm{C}, 60 \mathrm{RPM}$ and 3) methanol, at $65^{\circ} \mathrm{C}, 90 \mathrm{RPM}$ using a

Table 1 In vitro anti-fluke effectiveness of fifteen plant extracts

\begin{tabular}{|c|c|c|c|c|c|c|c|}
\hline \multirow[t]{2}{*}{ Plant extract } & & \multicolumn{2}{|c|}{ Reference control (\%) } & \multirow{2}{*}{$\begin{array}{l}\text { Untreated control (\%) } \\
0 \mathrm{mg} / \mathrm{L}\end{array}$} & \multicolumn{3}{|c|}{ Efficacy (\%) ${ }^{c}$} \\
\hline & & $10 \mathrm{mg} / \mathrm{L}$ & $50 \mathrm{mg} / \mathrm{L}$ & & $125 \mathrm{mg} / \mathrm{L}$ & $250 \mathrm{mg} / \mathrm{L}$ & $500 \mathrm{mg} / \mathrm{L}$ \\
\hline A. cornigera & $n=10$ & $100^{\mathrm{a}}$ & $100^{b}$ & $0^{\mathrm{a}}$ & $0^{\mathrm{a}}$ & $0^{a}$ & $0^{a}$ \\
\hline C. cajan & & $100^{\mathrm{a}}$ & $100^{b}$ & $0^{\mathrm{a}}$ & $0^{\mathrm{a}}$ & $0^{\mathrm{a}}$ & $100^{b}$ \\
\hline A. farnesiana & & $100^{\mathrm{a}}$ & $100^{b}$ & $0^{\mathrm{a}}$ & $0^{\mathrm{a}}$ & $0^{a}$ & $0^{\mathrm{a}}$ \\
\hline L. camara & & $100^{\mathrm{a}}$ & $100^{b}$ & $0^{\mathrm{a}}$ & $0^{a}$ & $0^{a}$ & $100^{b}$ \\
\hline H. rosa - sinensis & & $100^{\mathrm{a}}$ & $100^{b}$ & $0^{\mathrm{a}}$ & $0^{\mathrm{a}}$ & $0^{\mathrm{a}}$ & $0^{\mathrm{a}}$ \\
\hline B. frutescens & & $100^{\mathrm{a}}$ & $100^{\mathrm{b}}$ & $0^{\mathrm{a}}$ & $10 \pm 0.1^{\mathrm{a}}$ & $100^{b}$ & $100^{\mathrm{b}}$ \\
\hline M. azedarach & & $100^{\mathrm{a}}$ & $100^{b}$ & $0^{\mathrm{a}}$ & $7 \pm 0.11^{\mathrm{a}}$ & $7 \pm 0.11^{\mathrm{a}}$ & $13 \pm 0.11^{a}$ \\
\hline L. diversifolia & & $100^{\mathrm{a}}$ & $100^{b}$ & $0^{\mathrm{a}}$ & $0^{\mathrm{a}}$ & $0^{\mathrm{a}}$ & $0^{\mathrm{a}}$ \\
\hline C. spp & & $100^{\mathrm{a}}$ & $100^{\mathrm{b}}$ & $0^{\mathrm{a}}$ & $0^{\mathrm{a}}$ & $0^{\mathrm{a}}$ & $0^{\mathrm{a}}$ \\
\hline C. ambrosioides & & $100^{\mathrm{a}}$ & $100^{b}$ & $0^{\mathrm{a}}$ & $0^{a}$ & $0^{\mathrm{a}}$ & $0^{\mathrm{a}}$ \\
\hline P. auritum & & $100^{\mathrm{a}}$ & $100^{b}$ & $0^{\mathrm{a}}$ & $0^{\mathrm{a}}$ & $0^{\mathrm{a}}$ & $100^{b}$ \\
\hline M. sativa & & $100^{\mathrm{a}}$ & $100^{b}$ & $0^{a}$ & $0^{a}$ & $0^{\mathrm{a}}$ & $0^{\mathrm{a}}$ \\
\hline A. absinthium L. & & $100^{\mathrm{a}}$ & $100^{b}$ & $0^{a}$ & $0^{a}$ & $0^{a}$ & $0^{\mathrm{a}}$ \\
\hline O. basiliam & & $100^{\mathrm{a}}$ & $100^{\mathrm{b}}$ & $0^{\mathrm{a}}$ & $0^{\mathrm{a}}$ & $0^{\mathrm{a}}$ & $0^{\mathrm{a}}$ \\
\hline A. mexicana & & $100^{\mathrm{a}}$ & $100^{\mathrm{b}}$ & $0^{\mathrm{a}}$ & $100^{b}$ & $100^{b}$ & $100^{b}$ \\
\hline
\end{tabular}

${ }^{\mathrm{a}, \mathrm{b}} \mathrm{A}$ different letter between columns indicates statistically significant differences. Significant at $\mathrm{p}<0.05$ level. Control—nil mortality.

${ }^{\mathrm{C}}$ Average of three replicates \pm standard deviation.

${ }^{\mathrm{d}}$ Triclabendazole, average of three replicates \pm standard deviation.

${ }^{e}$ Destilled water, average of three replicates \pm standard deviation. 
Table 2 Second assessment of anti-fluke effectiveness of five plant extracts

\begin{tabular}{|c|c|c|c|c|c|c|c|c|}
\hline \multirow{2}{*}{$\begin{array}{l}\text { Plant } \\
\text { extract }\end{array}$} & & \multicolumn{2}{|c|}{ Reference control (\%) $^{d}$} & \multirow{2}{*}{$\begin{array}{l}\text { Untreated control (\%) } \\
0 \mathrm{mg} / \mathrm{L}\end{array}$} & \multicolumn{4}{|c|}{ Efficacy $(\%)^{c}$} \\
\hline & & $10 \mathrm{mg} / \mathrm{L}$ & $50 \mathrm{mg} / \mathrm{L}$ & & $125 \mathrm{mg} / \mathrm{l}$ & $250 \mathrm{mg} / \mathrm{l}$ & $500 \mathrm{mg} / \mathrm{l}$ & $500 \mathrm{mg} / \mathrm{l}$ \\
\hline A. mexicana & $n=10$ & $100^{\mathrm{a}}$ & $100^{\mathrm{b}}$ & $0^{\mathrm{a}}$ & $93 \pm 0.06^{b}$ & $100^{\mathrm{a}}$ & $100^{\mathrm{a}}$ & $100^{\mathrm{a}}$ \\
\hline B. frutescens & & $100^{\mathrm{a}}$ & $100^{b}$ & $0^{\mathrm{a}}$ & $0^{\mathrm{a}}$ & $100^{\mathrm{b}}$ & $100^{\mathrm{b}}$ & $100^{b}$ \\
\hline L. camara & & $100^{\mathrm{a}}$ & $100^{b}$ & $0^{a}$ & $0^{a}$ & $0^{a}$ & $93 \pm 0.06^{b}$ & $100^{b}$ \\
\hline P. auritum & & $100^{\mathrm{a}}$ & $100^{\mathrm{b}}$ & $0^{\mathrm{a}}$ & $0^{\mathrm{a}}$ & $0^{\mathrm{a}}$ & $83 \pm 0.06^{b}$ & $100^{b}$ \\
\hline C. cajan & & $100^{\mathrm{a}}$ & $100^{\mathrm{b}}$ & $0^{a}$ & $0^{a}$ & $0^{a}$ & $93 \pm 0.06^{b}$ & $93 \pm 0.06^{b}$ \\
\hline
\end{tabular}

${ }^{a, b} \mathrm{~A}$ different letter between columns indicates statistically significant differences. Significant at $\mathrm{p}<0.05$ level. Control-nil mortality.

${ }^{\mathrm{C}}$ Average of three replicates \pm standard deviation.

${ }^{\mathrm{d}}$ Triclabendazole, average of three replicates \pm standard deviation.

eDestilled water, average of three replicates \pm standard deviation.

rotaevaporator $[16,17]$. The plant extracts were kept in the dark at $4^{\circ} \mathrm{C}$ until tested.

\section{Bioassays}

To determine the antihelmintic effect of the 15 plant extracts on the mortality of excysted flukes a series of in vitro experiments were undertaken. Newly excysted flukes were obtained by the artificial excysment of $F$. hepatica metacercariae following the methodology described by Ibarra and Jenkins [18].

\section{Formulation of plant extracts for screening}

All compounds were formulated as follows: $500 \mathrm{mg}$ of the compound were placed in a screw-capped $15 \mathrm{ml}$ Eppendorf $^{\ominus}$ tube to which $0.1 \mathrm{ml}$ of methanol were added to dissolve the extract. Then two fold dilutions using distilled water were made to prepare concentrations of 500, 250 and $125 \mathrm{mg} / \mathrm{L}$.

Plant extracts were placed in $\mathrm{NUNC}^{\ominus}$ culture dishes. Each well contained $1.6 \mathrm{~mL}$ of RPMI- $1640^{\circ}$ of the culture medium, $0.2 \mathrm{~mL}$ of solubilized extract and $0.2 \mathrm{ml}$ containing 10 liver flukes. Four wells were used as untreated controls, three containing only a complete medium (RPMI-1640 ${ }^{\circ}$ ), the last one containing a culture medium and $0.2 \mathrm{ml}$ of methanol. In addition there were four more wells containing triclabendazole (SOFOREN ${ }^{\oplus}$, Novartis) at a 10 and $50 \mathrm{mg} / \mathrm{L}$, respectively. Each test remained incubated at $37^{\circ} \mathrm{C}$ for four days under a $5 \%$
$\mathrm{CO}_{2}$ atmosphere; each experiment was replicated three times.

The plant extracts with in vitro anthelmintic efficacy higher than $80 \%$ were re-evaluated twice in order to confirm the results, and a concentration of $375 \mathrm{mg} / \mathrm{L}$ was added to calculate the lethal concentration to kill $50 \%, 90 \%$ and $99 \%$ of the flukes ( $\mathrm{LC}_{50}, \mathrm{LC}_{90}$ and $\left.\mathrm{LC}_{99}\right)$. All procedures were performed under aseptic conditions using a laminar flow hood.

\section{Test interpretation}

The flukes under study were examined at 24, 48 and 72 hours post-exposure. Activity was measured by comparing the survival of the treated flukes relative to those of the control group. At each evaluation time, these flukes without motility were considered as dead.

\section{Efficacy measurement}

The effectiveness of the plant extracts was assessed with the following formula [19]:

$$
\begin{aligned}
\text { Efficacy }(\%)= & \text { No. of flukes alive in control group- } \\
& \frac{\text { No. of flukes alive in treated group }}{\text { No. of flukes alive in control group }} \times 100
\end{aligned}
$$

When an extract showed an in vitro efficacy greater than $80 \%$, it was considered to possess fascioliscide activity.

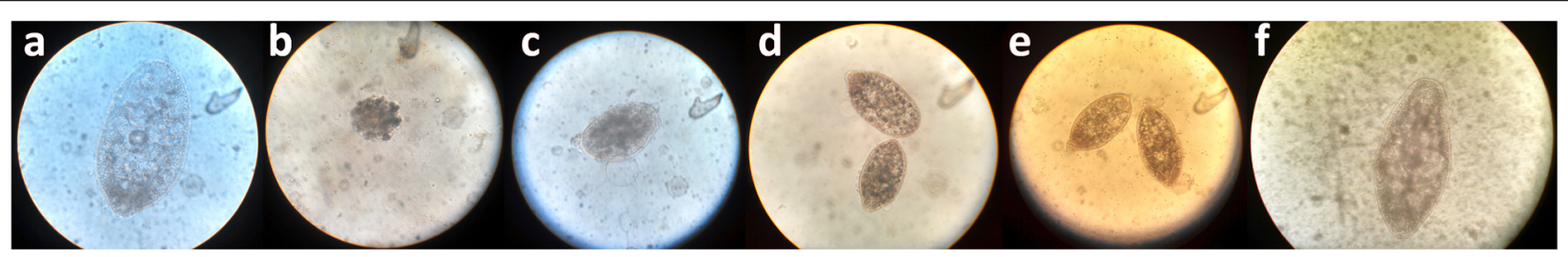

Figure 1 Flukicide activity of plant extracts. a. Untreated control flukes. b. Flukes treated with L. camara extract 72 hrs post exposition. Dead flukes being severely affected in the tegument and internal organs. c. Flukes treated with A. mexicana extract 72 hrs post exposition. Flukes showed no motility and internal changes. d. Flukes treated with $P$. auritum extract 72 hrs post exposition. Flukes showed no motility and no internal changes. e. Flukes treated with C. cajan extract 72 hrs post exposition. Flukes showed no motility and no internal changes. f. Flukes treated with B. frutescens extract 72 hrs post exposition. Flukes showed no motility, but presented internal changes and litghtly affected tegument. 
Table 3 Lethal concentration estimates from plant extracts with anthelmintic efficacy in vitro

\begin{tabular}{lllllllll}
\hline Plant extract & $\mathbf{L C}_{\mathbf{5 0}} \mathbf{( m g / L )}$ & $\mathbf{L C L}-\mathbf{U C L}$ & $\mathbf{L C}_{\mathbf{9 0}} \mathbf{( m g / L )}$ & $\mathbf{L C L}-\mathbf{U C L}$ & $\mathbf{L C}_{\mathbf{9 9}} \mathbf{( m g / L )}$ & $\mathbf{L C L}-\mathbf{U C L}$ & $\left.\mathbf{S D}^{\mathbf{2}} \mathbf{( d f}=\mathbf{1 0}\right)$ \\
\hline A. mexicana & 92.85 & $42.16-124.50$ & 210.44 & $166.78-306.78$ & 410.04 & $288.46-1135.26$ & \pm 2.197 & 5.893 \\
C. cajan & 382.73 & $327.13-444.12$ & 570.09 & $479.89-908.48$ & 788.9 & $603.92-1768.3$ & \pm 3.653 & 15.258 \\
B. frutescens & 369.96 & $318.77-419.83$ & 529.94 & $457.78-748.36$ & 710.34 & $567.74-1298.47$ & \pm 3.813 & 14.702 \\
\hline
\end{tabular}

LC50 - lethal concentration that kills $50 \%$ of the exposed flukes, LC90 - lethal concentration that kills $90 \%$ of the exposed flukes, LC 99 - lethal concentration that kills $99 \%$ of the exposed flukes, UCL: upper confidence limit; LCL: lower confidence limit, SD: standard deviation. $x^{2}-$ Chi-square; df: degree of freedom. Significant at $p<0.05$ level.

\section{Phytochemical screening}

The active extracts were subjected to phytochemical analysis to determine the presence of SM groups following standard published protocols [20,21].

\section{Statistical analyses}

A Kruskal-Wallis test, $\mathrm{P}<0.05$ was used to determine significant differences [22] and a PROBIT test was performed with POLO PLUS [23] to determine the $\mathrm{LC}_{50}$, $\mathrm{LC}_{90}$ and $\mathrm{LC}_{99}$ of the extracts that showed in vitro fascioliscide efficacy.

\section{Results}

\section{Efficacy of the extracts}

The flukes placed in the control wells remained alive and healthy throughout all the tests. From 15 plants evaluated (Table 1), five plant extracts at different dose levels effectively killed Fasciola hepatica $(\mathrm{P}<0.05)$. At a dose of $500 \mathrm{mg} / \mathrm{L}$, C. cajan, L. camara and P. auritum had an efficacy of $100 \%$, while $B$. frutescens and $A$. mexicana had a $100 \%$ efficacy at a dose of $125 \mathrm{mg} / \mathrm{L}$.

The five extracts showing in vitro anthelmintic activity greater than $80 \%$ are indicated in Table 2 . These were evaluated for a second time including a concentration of $375 \mathrm{mg} / \mathrm{L}$ to determine $\mathrm{LC}_{50}, \mathrm{LC}_{90}$ and $\mathrm{LC}_{99}$. The results were consistent with the previous one described above.

Figure 1 shows the flukicide activity before and after exposition with some plant extracts at $40 \times$.
Lethal concentration estimates at 50\%, $90 \%$ and $99 \%$ for exposed flukes to plant extracts

The slopes LC 50, LC 90 and LC 99\% in A. mexicana, C. cajan and $B$. frutescens tested plant extracts are shown in Table 3. A. mexicana showed significantly lower $\mathrm{LC}_{50}$, $\mathrm{LC}_{90}$ and $\mathrm{LC}_{99}$ than $C$. cajan and $B$. frutescens, but it was not possible to calculate LC for $P$. auritum and $L$. camara due to their high efficacy (100\%), but it was possible to be done in the two higher doses.

\section{Phytochemical screening}

Table 4 shows that most crude extracts contain MS such as alkaloids, phenolic compounds as well as coumarins, flavanones and flavonoids. Furthermore, sesquiterpen lactones, steroids, triterpenes and glycosides were also detected.

\section{Discussion}

Plant extracts currently represent a potencial alternative for the effective control of fasciolosis in domestic ruminants. However, since this area has been explored only to a limited extent, there is a manifest need to carry out new research to determine their potential against $F$. hepatica.

Jeyathilakan et al. [24] evaluated on Fasciola gigantica adults the efficacy of ethno-medicinal plant aqueous extracts such as Allium sativum, Lawsonia inermis, and Opuntia ficus indica in vitro in comparison with Oxyclozanide with efficacies from 40 - 100\%. Jeyathilakan et al.

Table 4 Results of phytochemical screening

\begin{tabular}{|c|c|c|c|c|c|}
\hline \multirow[t]{2}{*}{ Colorimetric reaction } & \multicolumn{5}{|c|}{ Plant extract } \\
\hline & L. camara & B. frutescens & P. auritum & C. cajan & A. mexicana \\
\hline Phenolic compounds (FeCl3) & ++ & + & ++ & ++ & + \\
\hline Coumarins (UV) & - & ++ & - & - & + \\
\hline Flavanones (NH3) & + Yellow & - & + Yellow & + Yellow & + Yellow \\
\hline Flavonoids (Shinoda) & - & - & + Red & + Orange & + Red \\
\hline Sesquiterpene lactones (Baljet) & + & - & + & + & + \\
\hline Alkaloids (Meyer) & +++ & +++ & +++ & +++ & +++ \\
\hline Alkaloids (Dragendorff) & +++ & +++ & +++ & +++ & +++ \\
\hline Steroids and triterpenoids (Liberman, Burchard) & ++ & ++ & + & + & + \\
\hline Glycosides (a-naphtol) & - & - & - & - & + \\
\hline
\end{tabular}

Symbology: -- negative; + weak positive; ++ positive; +++ strong positive. 
[25] evaluated the essential oils of Cymbopogan nardus and Azadirachta indica. The results indicate that the essential oil of citronella showed a potential anthelmintic activity (100\%) whereas neem oil did not show any significant effect. Their results indicated the potential for developing herbal-based anthelmintics to control $F$. gigantica in livestock.

In this study, five plant extracts showed fascioliscide activity: A. mexicana, B. frutescens, $L$. camara, $P$. auritum and C. cajan $(\mathrm{P}<0.05)$. Recent studies have reported that, at the same concentrations used in our study, A. mexicana extract had an anthelmintic of efficacy $100 \%[19,26]$. The latter findings show that at the doses tested, A. mexicana has an intrinsic anti-fluke activity; it also indicates that this extract may be an alternative to the chemical control of $F$. hepatica only after evaluation and in vivo toxicity studies. In this regard, studies by Ibarra-Moreno et al. [27] in CD1 mice demonstrated that the A. mexicana extract had no toxicity in renal or liver tissue.

To our knowledge, this is the first report of the anthelmintic effect of P. auritum, B. frutescens and C. cajan against $F$. hepatica. Although these plants have not been evaluated against trematodes before, they are found to possess some interesting and additional positive characteristics which deserve to be considered for future in vivo studies. For example, Ghanem et al. [28] reported a protective and an antioxidant effect in the plants of the Piperaceae family as well in $P$. auritum with cultured hepatocytes of mice. In addition, Estrada et al. [29] mention that acute toxicity tests show that the intake of extracts of different polarities of $P$. auritum involves no health risks. Kundu et al. [30] have also found in the $C$. cajan extract a hepato protective effect on mice. Since there are no reported toxic effects of these plants, it is possible to obtain a similar in vivo effect by direct administration to ruminants.

Up to now there have been no reports of anti-fluke effectiveness for L. camara despite its well - known toxicity in cattle and sheep. This is the first report of in vitro anthelmintic activity in the $L$. camara extract. However, it is necessary to consider the undesirable effects such as photosensitivity and liver disorders that are caused in the animals that consume this plant. If this plant demonstrates great anthelmintic activity in continued studies, there will be sufficient reason for further study in order to identify the causal agents responsible for this toxicity. It is, therefore, convenient to find other species of Lantana spp that have no toxicity reports [31].

Secondary metabolites such as alkaloids, terpenes, tannins or flavonoids contained in crude plant extracts have been related to parasiticidal activity [32-35]. Nevertheless, since these are not the only compounds that these and other plant species possess, it would be wrong to discard the effect of other bioactive compounds. Hence, it is necessary to determine the chemical composition of the extracts that show anthelmintic efficacy. Interestingly, all extracts gave a positive reaction for alkaloids. The literature shows reports of the presence of these compounds in L. camara [36], B. frutescens [37], and $P$. auritum [38], but not in C. cajan and A. mexicana. It is likely that the positive reactions in the latter species are due to the presence of nitrogen compounds such as amino acids or other amines of a non-alkaloid origin. These alkaloids are probably responsible for the biological activity; however, there are reports of nonnitrogenous substances isolated from these plants with biocide activity as well as pentacyclic triterpenoids isolated from L. camara [39] and sterols and sesquiterpene lactones isolated from C. cajanus [40] and A. mexicana [41], respectively.

Consequently, the present study represents preliminary information for the continuing research to demonstrate whether the data obtained can be amplified or not in order to get their SM to determine finally whether it is one SMs or a combination of SM responsible for fascioliscide activity.

\section{Conclusion}

Of the fifteen extracts tested, five showed promising in vitro fascioliscide efficacy, thus indicating that they could possibly be strong candidates for further biological and toxicological analyses aimed at demonstrating their real potential for liver fluke control in ruminants.

\section{Competing interests}

The authors of this manuscript have no financial or personal relationships with other people or organizations that could inappropriately influence or bias the content of the paper.

Authors' contributions

FIV, MAAD, YVM and JGAA contributed to conception and design of the study. JMAM, AMGB were responsible for execution and data collection. JMAM and MAAD were primarily responsible for data analysis and interpretation and all authors were involved in drafting the manuscript critical reading, editing and final approval of the submitted version.

\section{Acknowledgments}

This research was supported by the Council of Science and Technology (CONACYT, Mexico) and Project UNAM-DGAPA-PAPIIT IN 220313. We are thankful to Dr. Estephanie Ibarra Moreno, for her kind technical assistance in the evaluation of extracts.

\section{Author details}

${ }^{1}$ Departamento de Parasitología, Facultad de Medicina Veterinaria y Zootecnia, Universidad Nacional Autónoma de México. Cd. Universitaria, C.P. 04510 México, DF, Mexico. ${ }^{2}$ Centro de Enseñanza Investigación y Extensión en Ganadería Tropical, Facultad de Medicina Veterinaria y Zootecnia, Universidad Nacional Autónoma de México, Km. 5.5, Carretera Federal Tlapacoyan-Martínez de la Torre, C.P. 93600 Veracruz, Mexico. ${ }^{3}$ Lab. de Fitoquímica, UBIPRO, Facultad de Estudios Superiores Iztacala, UNAM, Avenida de los Barrios 1, C.P. 54090 Edo. de México, Mexico.

Received: 25 September 2014 Accepted: 19 February 2015 Published online: 27 February 2015 


\section{References}

1. OPS (Organización Panamericana de la Salud). Zoonosis y enfermedades transmisibles comunes al hombre y a los animales. USA: OPS; 2003.

2. FAO. (Food and Agriculture Organization of the United Nations). Resistencia a los antiparasitarios. Estado actual con énfasis en América Latina. Italy: FAO; 2003.

3. Ceballos L, Moreno L, Alvarez L, Shaw L, Fairweather I, Lanusse C. Unchanged triclabendazole kinetics after co-administration with ivermectin and methimazole: failure of its therapeutic activity against triclabendazole-resistant liver fluke. BMC Vet Res. 2010;6:1-8.

4. Olaechea F, Lovera V, Larroza M, Raffo F, Cabrera R. Resistance of Fasciola hepatica against triclabendazole in cattle in Patagonia (Argentina). Vet Parasitol. 2011;178:364-6

5. Anthony JP, Fyfe L, Smith $H$. Plant active components - a resource for antiparasitic agents? Trends Parasitol. 2005;21:462-8.

6. Vera-Montenegro Y, Ibarra-Velarde F, Ramirez-Avila G, Munguia-Xochihua J. In vitro fasciolicide activity of some plant extracts against newly excysted flukes. Ann NY Acad Sci. 2008;1149:180-2.

7. Singh TU, Kumar D, Tandan SK, Mishra KS. Inhibitory effect of essential oils of Allium sativum and Piper longumon spontaneous muscular activity of liver fluke, Fasciola gigantica. Exp Parasitol. 2009;123:302-8.

8. Ferreira JFS, Peaden P, Keiser J. In vitro trematocidal effects of crude alcoholic extracts of Artemisia annua, A. absinthium, Asimina triloba, and Fumaria officinalis: trematocidal plant alcoholic extracts. Parasitol. 2011;109:585-1592.

9. INEGI (Instituto Nacional de Estadística, Geografía e Información). Boletín de información oportuna del sector agropecuario. Aguascalientes: Instituto Nacional de Estadística, Geografía e Informática; 2010.

10. Cano ALM. Flora Medicinal de Veracruz I. Inventario Etnobotánico. México: Universidad Veracruzana; 1997.

11. Columba M. Plantas medicinales utilizadas en el estado de Morelos. México: Universidad Autónoma del estado de Morelos; 2007.

12. Rodríguez A, Coombes J, Jimenez R. Plantas silvestres de Puebla: herbario y jardín botánico BUAP. México: Herbario BUAP; 2009.

13. Fernandes FF, Freitas SEP. Acaricidal activity of an oleoresinous extract of Copaifera reticulata (Leguminosae: Caesalpinioideae) against larvae of the southern cattle tick, Rhipicephalus (Boophilus) microplus (Acari: Ixodidae). Vet Parasitol. 2007;147:150-4.

14. Camurça-Vasconcelos ALF, Bevilaqua CML, Morais SM, Maciel MV, Costa CTC, Macedo ITF, et al. Anthelmintic activity of Lippia sidoides essential oil on sheep gastrointestinal nematodes. Vet Parasitol. 2008;154:167-70.

15. Alonso-Díaz MA, Torres-Acosta JFJ, Sandoval-Castro CA, Hoste H. Comparing the sensitivity of two in vitro assays to evaluate the anthelmintic activity of tannin rich plant extracts against Haemonchus contortus. Vet Parasitol. 2011;181:360-4.

16. Harnborne JB. Phytochemical phylogeny; proceedings of the Phytochemical Society Symposium. London: Academic; 1970.

17. Trease GE. Tratado de farmacognosis. México: Interamericana; 1987.

18. Ibarra OF, Jenkins DC. An in vitro screen for new fasciolicidal agents. Z Parasitenkd. 1984;70:655-61.

19. Ibarra-Moreno S, Ibarra-Velarde F, Ávila-Acevedo JG. In vitro evaluation of anthelmintic activity with hexane, methanol and ethyl acetate with extracts processed and obtained from some mexican plants used in traditional medicine based on ethno Botanical Studies. Am J Plant. 2012;3:506-11.

20. Evans WC. Trease and Evans' Pharmacognosy. 15th ed. Edinburgh, U.K: Saunders Ltd; 2002.

21. Sampietro DA, Sgariglia M, Soberón J, Quiroga E, Vattuone M. (2009) Colorimetric reactions. In: Sampietro D, Catalan C, Vattuone M, editors. Isolation, Identification and Characterization of Allelochemicals/Natural Products. U.S.A: CRC Press; 2009. p. 73-101.

22. Statgraphics Centurion XVI (Computer program) Statpoint Technologies, INC. version 16.1.17(64-bits) EUA, 2011.

23. LeOra Software In: ROBERTSON JL, PREISLER HK, RUSSELL RM. (Eds.) A user's guide to Probit or Logic Analysis. Berkley, USA; 2003.

24. Jeyathilakan N, Murali k, Anandaraj A, Latha BR, Abdul Basith S. Anthelmintic activity of essential oils of Cymbopogan nardus and Azadirachta indica on Fasciola gigantica. Tamilnadu J Vet Anim Sci. 2010;6(5):204-9.

25. Jeyathilakan N, Murali K, Anandaraj A, Abdul-Basith S. In vitro evaluation of anthelmintic property of ethno-veterinary plant extracts against the liver fluke Fasciola gigantica. J Parasit Dis. 2012;36(1):26-30.
26. Elango G, Rahuman AA. Evaluation of medicinal plant extracts against ticks and fluke. Parasitol Res. 2011;108(3):513-19.

27. Ibarra-Moreno S, Ibarra-Velarde F, Ávila-Acevedo JG. Obtaining the minimum lethal dose against Fasciola hepatica in vitro using plant extract hexanes with anthelmintic activity and toxicity evaluation on CD1 male mice. Am J Plant Sci. 2012;3:899-903.

28. Ghanem MTM, Radwan HMA, Mahdy ESM, Elkholy YM, Hassanein HD, Shahat AA. Phenolic compounds from Foeniculum vulgare (Subsp. Pipertum) (Apiaceae) herb and evaluation of hepatoprotective antioxidant activity. Phcog Res. 2012;4:104-8.

29. Estrada-Reyes R, Martínez-Laurrabaquio A, Ubaldo Suárez D, Araujo-Escalona AG. Neuropharmacological studies of Piper auritum Kunth (Piperaceae): antinociceptive and anxiolytic-like effects. J Med Plants Res. 2013;7 (23):1718-29.

30. Kundu R, Dasgupta S, Biswas A, Bhattacharya A, Pal BC, Bandyopadhyay D, et al. Cajanus cajan Linn. (Leguminosae) prevents alcohol-induced rat liver damage and augments cytoprotective function. J Ethnopharmacol. 2008;118:440-7.

31. Ghisalberti EL. Review Lantana camara L (Verbenaceae). Fitoterapia. 2000;71:467-86.

32. Hoste H, Jackson F, Athanasiadou S, Thamsborg SM, Hoskin SO. The effects of tannin-rich plants on parasitic nematodes in rumiants. Trends Parasitol. 2006;6:253-61.

33. Athanasiadou S, Githiori J, Kyriazakis I. Medicinal plants for helminth parasite control: facts and fiction. Animal. 2007;1:1392-400.

34. Calzada F, Yépez-Mulia L, Tapia-Contreras A. Effect of Mexican medicinal plant used to treat trichomoniasis on Trichomonas vaginalis trophozoites. J Ethnopharmacol. 2007;113:248-51.

35. Von son-de Fernex E, Alonso-Díaz MA, Valles-De la Mora B, Capetillo-Leal CM. In vitro anthelmintic activity of five tropical legumes on the exsheathment and motility of Haemonchus contortus infective larvae. Exp Parasitol. 2012;131:413-8.

36. Ntalli NG, Caboni P. Botanical Nematicides: A Review. J Agric Food Chem. 2012;60:9929-40.

37. Montgomery CT, Cassels B, Maurice S. The Rhoeadine Alkaloids. J Nat Prod. 1983:46:441-53.

38. Parmar VS, Jain SC, Bisht KS, Jain R, Taneja P, Jha A, et al. Phytochemistry of the genus piper. Phytochemistry. 1997;46:597-673.

39. Siddiqui BS, Raza SM, Begum S, Siddiqui S, Firdous S. Pentacyclic triterpenoids from Lantana camara. Phytochemistry. 1995;38:681-5.

40. Akihisa T, Nishimura Y, Nakamura N, Roy K, Ghosh P, Thakur S, et al. Sterols of Cajanus cajan and three other leguminosae seeds. Phytochemistry. 1992;31:1769-8.

41. Mata R, Delgado G, Romo DVA. Sesquiterpene lactones of Artemisia mexicana var. Angustifolia. Phytochemistry. 1984;23:1665-8.

\section{Submit your next manuscript to BioMed Central and take full advantage of:}

- Convenient online submission

- Thorough peer review

- No space constraints or color figure charges

- Immediate publication on acceptance

- Inclusion in PubMed, CAS, Scopus and Google Scholar

- Research which is freely available for redistribution 